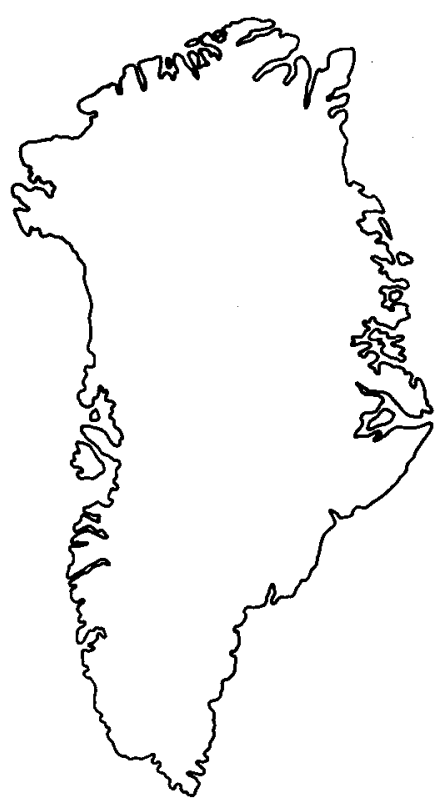

\title{
Early Cambrian Salterella from North-West Greenland
}

\author{
Ellis L. Yochelson and John S. Peel
}

\begin{abstract}
The small, cone-like Salterella expansa Poulsen, 1927, from the Early Cambrian Wulff River Formation is redescribed and considered to be a junior synonym of $S$. rugosa Billings, 1861 . Both the original material and new collections from Inglefield Land, North-West Greenland, are illustrated.

E.L.Y., U.S. Geological Survey, Washington D.C. 20560, U.S.A.

J.S.P., Grønlands Geologiske Undersøgelse, Øster Voldgade 10, DK-1350 København K, Danmark.
\end{abstract}

Salterella Billings, 1861 is a small $(c .1 \mathrm{~cm})$ cone-like shell first described from Labrador which is widespread and locally common in rocks of Early Cambrian age (Yochelson, 1977). Although first interpreted as a pteropod gastropod, Poulsen (1927) followed the then current opinion of Clark (1925) in considering Salterella to be the oldest known cephalopod. More recently, Salterella has been interpreted as a member of an extinct phylum (Yochelson, 1977) and close relationship to the Cephalopoda has been discounted.

More than half a century ago, Poulsen (1927) described Salterella expansa from Lower Cambrian limestones of the Wulff River Formation of Inglefield Land, North-West Greenland (fig. 1). The specimens were collected by Lauge Koch during the Danish Bicentenary Expedition to North Greenland of 1920-1923. Additional collections were made by J. C. Troelsen during 1939 and 1941 and were subsequently described by Poulsen (1958). One of us (J.S.P.) visited Inglefield Land during the summer of 1977 and was able to make a third collection of $S$. expansa. These three groups of collections, spanning 50 years, provide the base for the present re-evaluation of $S$. expansa. It is concluded that $S$. expansa is a junior synonym of $S$. rugosa Billings, the type species of Salterella.

\section{Stratigraphic and geographic distribution}

Poulsen (1927, p. 251) recorded Salterella expansa from the Wulff River Formation at Cape Kent, the Kap Kent of present usage, north-eastern Inglefield Land (fig. 1). In reviewing this occurrence, Poulsen (1958) gave the locality of his original material as Wulffs Elv (= Wulff Elv). Troelsen's collections, described by Poulsen (1958), were derived from the Wulff River Formation at Blomsterbækken and from two localities at Marshall Bugt, to 


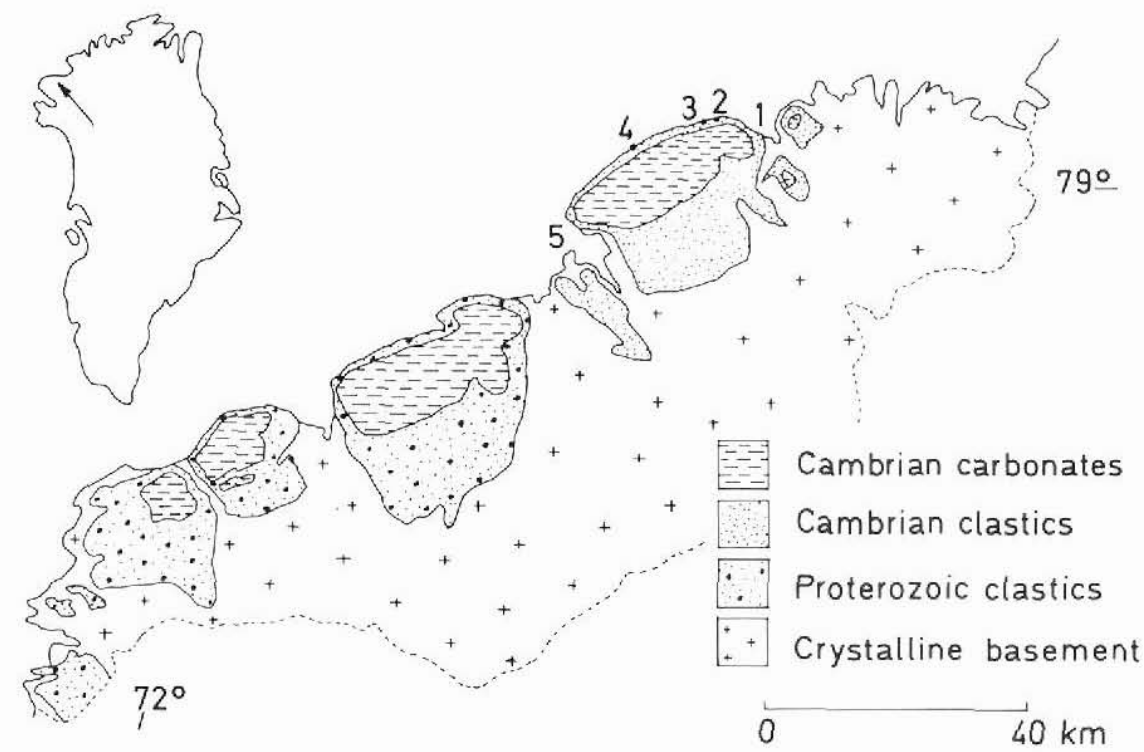

Fig. 1. Simplified geological map of Inglefield Land showing localities mentioned in the text. The Wulff River Formation (c. $30 \mathrm{~m}$ ) forms part of a dominantly carbonate sequence of Early-Late(?) Cambrian age which is at least $200 \mathrm{~m}$ thick. 1, Dallas Bugt; 2, Kap Kent; 3, Wulff Elv; 4, Blomsterbækken; 5, Marshall Bugt. Based on Dawes (1976) and unpublished observations by J. D. Collinson, P. R. Dawes and J. S. Peel

the south-west. The material collected during 1977 came from the Wulff River Formation at Dallas Bugt and from the plateau surface to the south-west of the bay.

Despite their common derivation, the collections described from the Wulff River Formation by Poulsen in 1927 and 1958 have only a single species in common, namely $S$. expansa. However, the presence of olenellid species in both lots clearly demonstrates their Early Cambrian age, most probably the late Early Cambrian Bonnia-Olenellus zone. Poulsen (1958), in reviewing the faunas, commented on differences in lithology and concluded that the lack of common species might indicate the presence of stratigraphically distinct faunules. He noted that most of his 1927 material was found in impure sandy limestones while the material collected by Troelsen was mainly fairly pure limestones. However, in the case of Salterella, it should be noted that Troelsen (1950) recorded this genus from grey calcareous sandstones with cross-bedding at Blomsterbækken, although it is uncertain from Troelsen's account if $S$. expansa is also present in the subjacent limestones.

The material collected during 1977 was collected from about $2 \mathrm{~m}$ of yellowish grey calcareous sandstones with calcareous nodules which appeared to represent burrow infillings. The sandstones occur about $12 \mathrm{~m}$ above the base of the Wulff River Formation, which is approximately $25-30 \mathrm{~m}$ thick in the area around Dallas Bugt. The rest of the formation appears to be principally composed of grey-brown, lime muds with a distinctive brown weathering, dendritic pattern of dolomite infilled burrows on bedding planes. Olenellids in the limestones below and above the Salterella sandstones indicate an Early Cambrian age. 


\section{Note on nomenclature}

In the redescription of Salterella expansa, Poulsen (1958, p. 10) designated one of the specimens collected by Troelsen from Marshall Bugt as the holotype of his 1927 species. Clearly, this is a lapsus on the part of the author since the type specimen must be selected from the original lot if this is still in existence. In 1927 Poulsen illustrated one isolated specimen and parts of a thin-section containing numerous specimens. No other material available to him at that time is known to exist.

The external surface of Salterella provides little information concerning the characteristics of the species. Consequently, it seems preferable to select a thin-sectioned specimen as the lectotype of $S$. expansa. Of all the individuals on Poulsen's (1927) thin section the only one which may not be selected as lectotype of $S$. expansa is the specimen assigned to Salterella sp. ind. by Poulsen (1927, pl. 14, fig. 13) for it was clearly excluded from the original species concept by the author of the species. There is no requirement that a lectotype be a previously figured specimen, as long as it is certainly part of the original lot. In the case of the thin-section there can be no doubt on this point. In consequence, MGUH 15090, the specimen illustrated in fig. 5B is here designated as lectotype of Salterella expansa Poulsen, 1927. The need for designation of a lectotype for $S$. expansa is unaffected by the present subjective synonymisation of this species with $S$. rugosa.

\section{Systematic palaeontology}

Phylum Agmata Yochelson, 1977

Family Salterellidae Walcott, 1886

Discussion. Poulsen (1932) referred Salterella to a new family, Salterellidae, of the nautiloid cephalopods, seemingly overlooking Walcott's (1886) proposal of the same term. As noted above, Salterella is no longer considered to be a cephalopod (Yochelson, 1977).

Fig. 2. Salterella rugosa, Wulff River Formation, Inglefield Land. A, longitudinal section of a small specimen broken at the aperture and mostly filled by matrix; internal deposits are confined to the area just above the apex, $\times 15$. MGUH 15086 from J. C. Troelsen collection 42, Marshall Bugt. $B$, longitudinal section of a mature conch showing the internal deposits pierced by a central tube; the outer wall is not preserved on the right side of the illustration, $\times 10$. MGUH 15087 from J. C. Troelsen collection 538, west of Blomsterbækken.
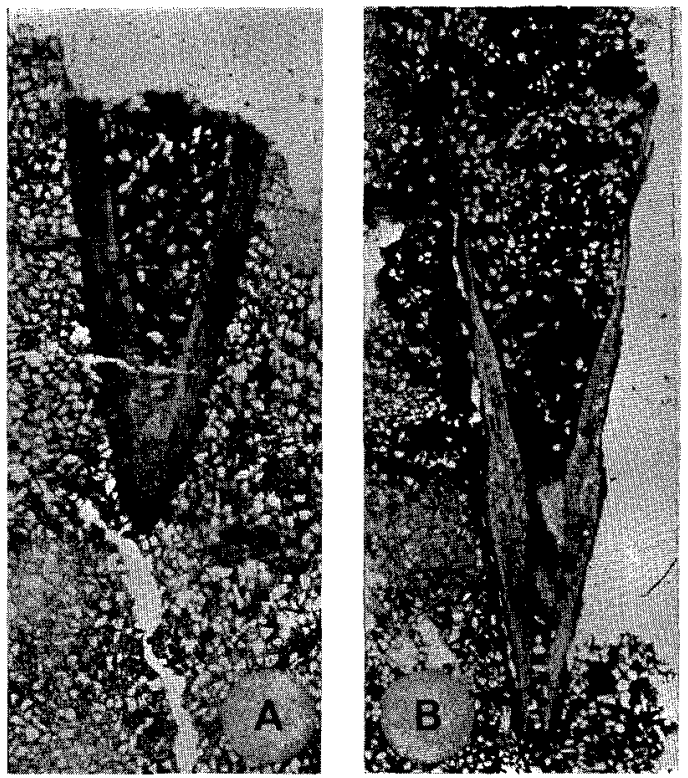

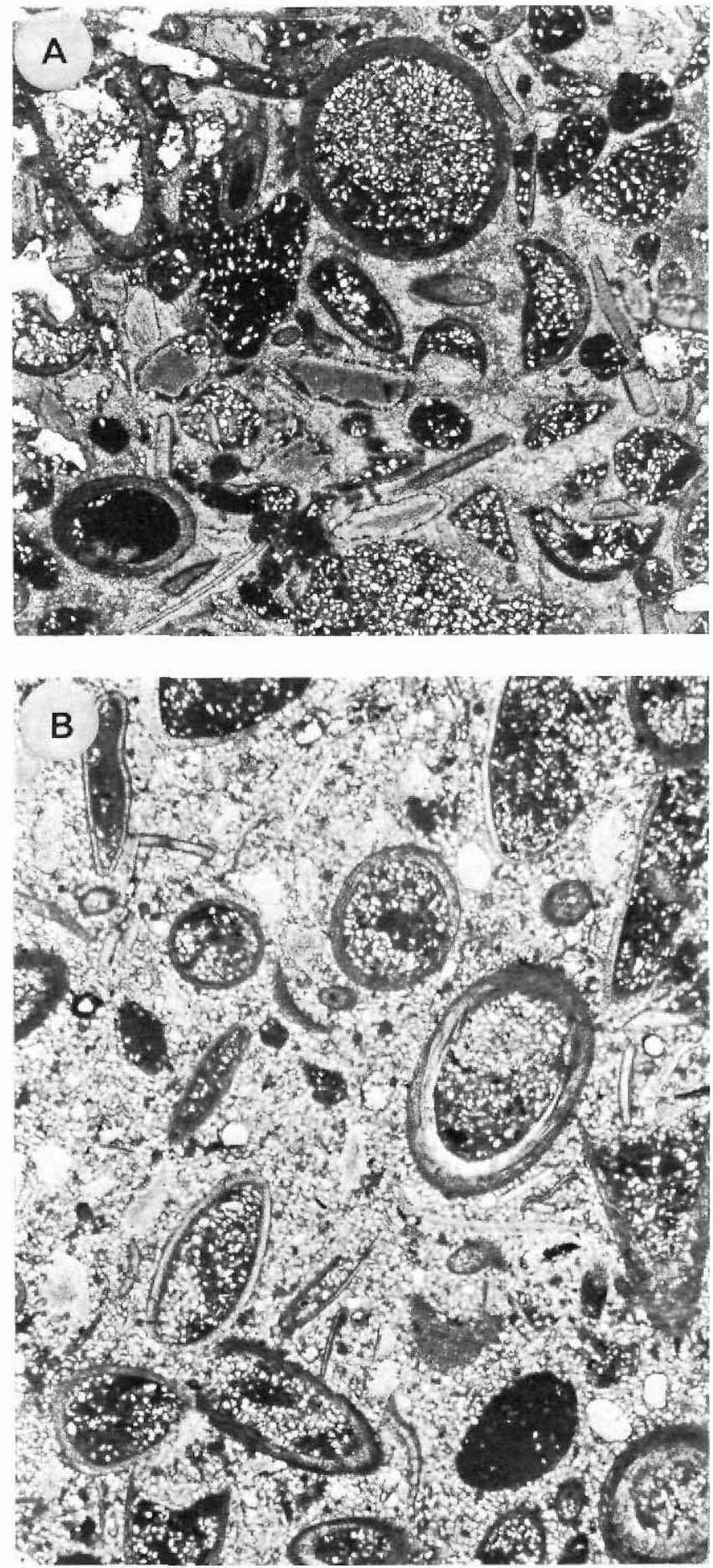

Fig. 3. Salterella rugosa, Wulff River Formation, Inglefield Land. A, thin section of conchs, principally in cross-section, $\times 10$. MGUH 15088 from GGU sample 242127 , plateau surface immediately south-west of Dallas Bugt. B, thin section of conchs in longitudinal, transverse and oblique transverse orientations, $\times 10$. MGUH 15089 from GGU sample 242112, Dallas Bugt. 


\section{Genus Salterella Billings, 1861}

Type species. Salterella rugosa Billings, 1861.

\section{Salterella rugosa Billings, 1861}

Figs 2-5

Salterella rugosa Billings, 1861, p. 954, fig. 362.

Salterella rugosa, Billings, 1864, p. 17-18, fig. 22.

Salterella expansa Poulsen, 1927, p. 251, Pl. XIV, figs 10-12.

Salterella sp. ind., Poulsen, 1927, p. 251-2, PI. XIV, fig. 13.

Salterella rugosa, Poulsen, 1932, p. 32-34, figs 5, 6; pl. 7, figs 11-15; Pl. 8, figs 1, 2.

Salterella expansa, Poulsen, 1958, p. 10, PI. 1. figs 2, 3.

Salterella rugosa, Griffin \& Yochelson, 1975, 221-227, figs 1-9.

Salterella rugosa, Yochelson, 1977. p. 442-8, Pl. 1, figs 1-4; Pl. 2, figs 1, 2-7; Pl. 3, figs 4, 5.

Figured material. MMH 2215-MMH 2217; MGUH 15090, the lectotype; MGUH 15086 from J. C. Troelsen collection 42, MGUH 15087 from J. C. Troelsen collection 538; MGUH 15089 from GGU sample 242112, MGUH 15088 from GGU sample 242127.

Description. Relatively narrow, uniformly tapering conchs lacking prominent lamination of the inner deposits. Apertural angle 17-20 degrees, seemingly constant throughout ontogeny. Apertural cavity deep, more than half the length of the conch at almost all growth stages. Apertural rim elongate and tapering. Inner deposits steeply inclined, extending up the cavity about half way from the base of the central tube to the apertural rim. Inner laminations exceedingly obscure.

Discussion. Two species of Salterella have been described from Greenland, namely $S$. expansa from Inglefield Land, and $S$. rugosa from East Greenland, more than a thousand miles to the south-east (Poulsen, 1932; Griffin \& Yochelson, 1975). Poulsen's description of these species was formulated at a time when the concept of Salterella differed radically from that employed today. Through the study of a number of additional collections it has become apparent that the size and composition of the grains incorporated within the conch interior may vary considerably in presumed relationship to the habitat. This variation may also affect the degree of expression of the lamination in the conch deposits. For example, topotype specimens of $S$. rugosa contain tiny grains of quartz and feldspar whereas specimens of the same species from East Greenland selected rhombs of dolomite for inclusion within the conch (Griffin \& Yochelson, 1975).

Under these circumstances, the angle of expansion of the conch and the shape of the apertural cavity seem to be the most reliable characters to use in defining species. However, in view of the risk of removal of the conch wall by solution and abrasion (Yochelson, Pierce \& Taylor, 1970) it is necessary to base these observations on oriented thin sections.

Taking these points into account leads us to the conclusion that the Inglefield Land specimens cannot be excluded from $S$. rugosa. Accordingly, S. expansa Poulsen is considered to be a junior subjective synonym of $S$. rugosa Billings. This opinion is based on direct comparison of the type material of $S$. rugosa with the Greenland specimens.

The specimens from Inglefield Land are distinguished from $S$. conulata Clark by the blunter apex and broader conch of that species. They also have a deeper apertural cavity and a thinner wall, with more elongate apertural rim, than $S$. conulata. S. pulchella Billings from 


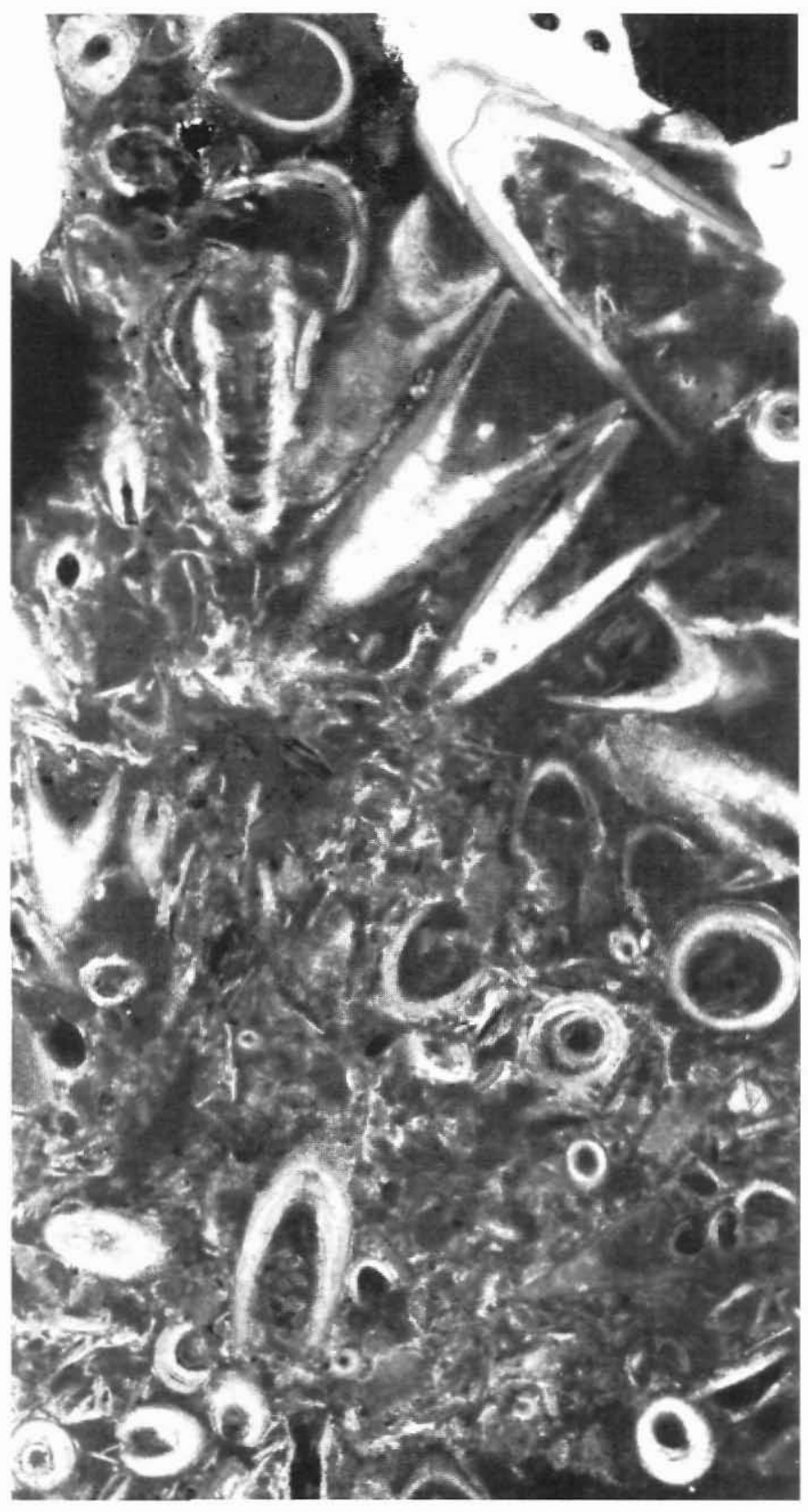

Fig. 4. Salterella rugosa, Wulff River Formation, Inglefield Land. The thin section from which Poulsen (1927) took his illustrations of S. expansa. MMH 2215 , the original of Poulsen's pl. 14 , fig. 11 . is the cross-section in the lower left corner. Additional individual specimens are illustrated in fig. 5 . The section is slightly thicker than those shown in figs 2 and 3. Kap Kent, $\times$ 10.

Labrador and $S$. maccullochi (Salter) from Scotland are still too poorly known to compare with the Greenland specimens.

Since Salterella was considered to be a cephalopod by Clark (1925) and Poulsen (1927, 1932, 1958), considerable emphasis has been placed on the interpretation of the central 

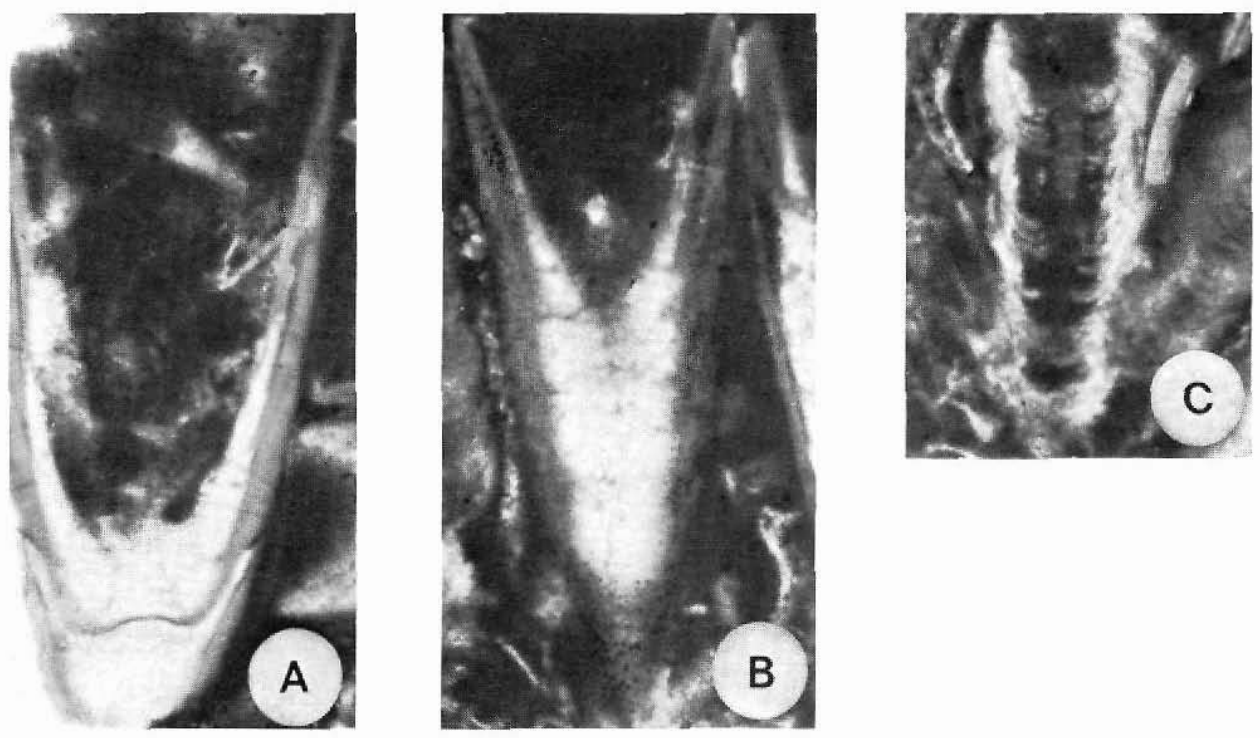

Fig. 5. Salterella rugosa, Wulff River Formation, Inglefield Land. A, MMH 2216, the original of Poulsen (1927, pl. 14, fig. 12), $\times 15$. The specimen is located in the upper right corner of fig. 4 . B, MGUH 15090, the lectotype of Salterella expansa Poulsen, here designated, $\times 15$. The specimen is located in the upper centre of fig. 4. C, MMH 2217, Salterella sp. ind. of Poulsen (1927, pl. 14, fig. 13), $\times 15$. The specimen is located near the upper centre of fig. 4 .

tube as an apparent siphuncle. The specimen which Poulsen (1927) distinguished as an indeterminate species (fig. 5C) shows this feature well. The specimen is atypical in shape because the conch wall is missing. The inner laminated deposits are consequently modified by solution or wear. The presumed septa are nothing more than discontinuities in the inner laminae.

Acknowledgments. Thin-sections and photographs for figs 2 and 3 were prepared by K. Moore, U.S. Geological Survey. S. Floris, Geologisk Museum, Copenhagen, supplied the negative of Poulsen's original thin-section (figs 4 and 5). T. E. Bolton, Geological Survey of Canada, loaned type specimens in his care. The late Christian Poulsen, Copenhagen, kindly donated specimens of Greenland Salterella to the National Museum of Natural History, Washington D.C., U.S.A. writing "I welcome a restudy of the genus Salterella ... to contribute to the understanding of this problematic creature".

MMH and MGUH refer to specimens in the type collections of the Geologisk Museum, Copenhagen.

\section{References}

Clark, T. H. 1925: On the nature of Salterella. Trans. Roy. Soc. Canada 19, 1-12.

Dawes, P. R. 1976: Precambrian to Tertiary of northern Greenland. In Escher, A. \& Watt, W. S. (edit.) Geology of Greenland, 248-303. Copenhagen: Geol. Surv. Greenland.

Griffin, W. L. \& Yochelson, E. L. 1975: Mineralogy of Early Cambrian Salterella rugosa from East Greenland. Bull. geol. Soc. Denmark 24, 221-227.

Poulsen, C. 1927: The Cambrian, Ozarkian and Canadian faunas of Northwest Greenland. Meddr Gronland 70(1), 2, 233-343. 
Poulsen, C. 1932: The Lower Cambrian faunas of East Greenland. Meddr Grønland 87(6), $66 \mathrm{pp}$.

Poulsen, C. 1958: Contribution to the palaeontology of the Lower Cambrian Wulff River Formation. Meddr Gronland 162(2), 25 pp.

Troelsen, J. C. 1950: Contributions to the geology of Northwest Greenland, Ellesmere Island and Axel Heiberg Island. Meddr Grønland 149(7), 86 pp.

Walcott, C. D. 1886: Second contribution to the studies on the Cambrian of North America. Bull. U.S. geol. Surv. 30, $368 \mathrm{pp}$.

Yochelson, E. L. 1970: The early Cambrian fossil Salterella conulata Clark in eastern North America. Prof. Pap. U.S. geol. Surv. 683-B, 1-10.

Yochelson, E. L. 1977: Agmata, a proposed extinct phylum of early Cambrian age. J. Paleont. 51, $437-454$.

Yochelson, E. L., Pierce, J. W. \& Taylor, M. E. 1970: Salterella from the Lower Cambrian of Central Nevada. Prof. Pap. U.S. geol. Surv. 643-H, 7 pp. 